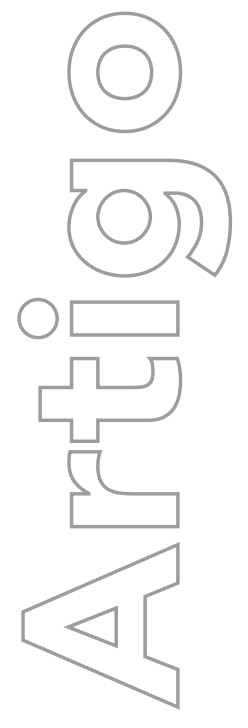

revista

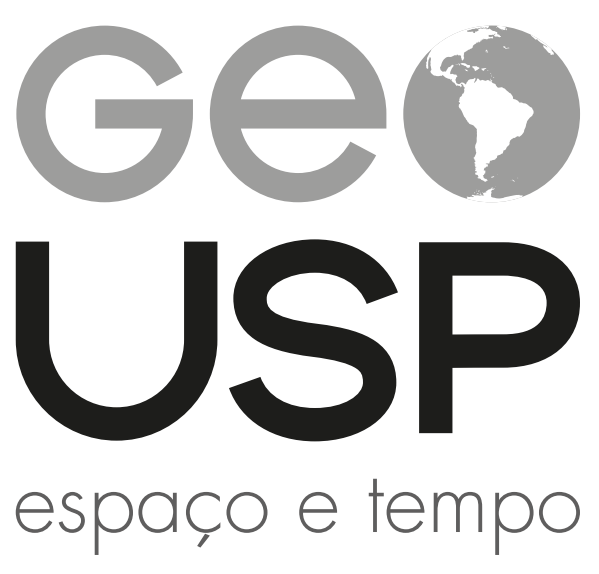

Volume $25 \cdot n^{\circ} 2$ (2021)

ISSN 2179-0892

\section{José e a cidade: uma incursão geográfica na poesia política de Carlos Drummond de Andrade}

Felipe Cabañas da Silva

Universidade de São Paulo. Faculdade de Filosofia, Letras e Ciências Humanas. São Paulo. São Paulo. Brasil fecdasilva@yahoo.com.br (1) 0000-0002-2364-7486

\section{e-172545}

Como citar este artigo:

CABAÑAS DA SILVA, F. José e a cidade: uma incursão geográfica na poesia política de Carlos Drummond de Andrade. Geousp, v. 25, n. 2, e-172545, 2021, ISSN 2179-0892.

Disponível em: https://www.revistas.usp.br/geousp/article/ view/172545. doi: https://doi.org/10.11606/issn.2179-0892. geousp.2021.172545.

\section{(c)}

Este artigo está licenciado sob a Creative Commons Attribution 4.0 Licence 


\title{
José e a cidade: uma incursão geográfica na poesia política de Carlos Drummond de Andrade ${ }^{1}$
}

\section{Resumo}

Este artigo se insere nos estudos que relacionam geografia e literatura e tem como objetivo analisar a obra "José" (1942), de Carlos Drummond de Andrade, que é parte da fase mais politizada do autor (a primeira metade da década de 1940), que inclui ainda os livros Sentimento do mundo (1940) e A rosa do povo (1945). Para tanto, fizemos uma leitura crítica dos poemas, com enfoque geográfico, articulando a questão da política à vivência urbana na modernidade. Do ponto de vista teórico-metodológico, procuramos estabelecer um genuíno diálogo entre os versos e o pensamento geográfico, em que não há hierarquia entre os dois saberes e o discurso do poeta e do geógrafo se imiscuem. Por isso, também produzimos material cartográfico dialogando com o conteúdo literário.

Palavras-chave: Drummond. José. Modernidade. Cidade. Geografia e literatura.

\section{José and the city: a geographical incursion into the political poetry of Carlos Drummond de Andrade}

\begin{abstract}
This article is part of studies that relate geography and literature and aims to analyze the work "José" (1942), by Carlos Drummond de Andrade, which is part of the author's most politicized phase (the first half of the 1940s), which also includes the books Sentimento do mundo (1940) and A rosa do povo (1945). For this, we carry out a critical reading of the poems, with a geographical focus, articulating the issue of politics to urban living in modernity. From the theoretical and methodological point of view, we seek to establish a genuine dialogue between verses and geographical thought, in which there is no hierarchy between the two knowledges
\end{abstract}

1 Este artigo é um adaptação de um dos capítulos de tese de doutorado defendida no Departamento de Geografia da Universidade de São Paulo em 2019. 
and the discourse of the poet and the geographer are intermingled. For this reason, we also produce cartographic material in dialogue with literary content.

Keywords: Drummond. José. Modernity. City. Geography and literature.

\title{
José y la ciudad: una incursión geográfica en la poesía política de Carlos Drummond de Andrade
}

\begin{abstract}
Resumen
Este artículo es parte de los estudios que relacionan geografía y literatura y tiene como objetivo analizar la obra "José" (1942), de Carlos Drummond de Andrade, que es parte de la fase más politizada del autor (la primera mitad de la década de 1940), que también incluye los libros Sentimento do mundo (1940) y A rosa do povo (1945). Para tanto, realizamos una lectura crítica de los poemas, con un enfoque geográfico, articulando el tema de la política a la vida urbana en la modernidad. Desde el punto de vista teórico y metodológico, buscamos establecer un diálogo genuino entre los versos y el pensamiento geográfico, en el que no haya una jerarquía entre los dos conocimientos y el discurso del poeta y el geógrafo se entremezclan. Por esta razón, también producimos material cartográfico en diálogo con el contenido literario.
\end{abstract}

Palabras clave: Drummond. José. Modernidad. Ciudad. Geografía y literatura.

\section{Introdução}

Geografia e literatura têm feito nas últimas décadas um movimento de aproximação que cresce em relevância e produtividade. No Brasil, onde Antonio Candido (1969) identifica a importância dos romancistas na interpretação do país antes da formação das universidades, esse diálogo tende a ser muito rico e produtivo. Historicamente, a literatura foi impelida a pensar o país, seu espaço, seu território, suas regiões e seu povo. Dessa maneira, o geógrafo tende a encontrar nessa literatura farta matéria de diálogo.

Historicamente, no entanto, a geografia tendeu a privilegiar o diálogo com o romance, especialmente o realista, em detrimento de outros gêneros literários (Brosseau, 1996; Lafaille, 1989). Com essa predileção, perdem-se oportunidades de refletir sobre o espaço e, portanto, de (re)significar a geografia.

Este artigo visa ir além desses limites e propõe uma reflexão geográfica sobre a obra "José", de Carlos Drummond de Andrade, publicada em 1942 na antologia Poesias. Essa fase da 
poesia de Carlos Drummond de Andrade, na primeira metade da década de 1940, que se inicia com a publicação de Sentimento do mundo em 1940, e se encerra com a publicação de $A$ rosa do povo, em 1945, é a mais politizada do autor que Antonio Candido (2011, p. 85) considera o "maior poeta social da nossa literatura contemporânea".

É nesses anos que Drummond, já residindo no Rio de Janeiro, é convidado por Luís Carlos Prestes para ser coeditor do jornal Tribuna Popular, de orientação comunista (Andrade, 2007, p. 85). São os anos em que o grande poeta social mais chega perto de uma militância política de fato, embora tenha ficado pouco tempo no jornal, por "discordar da sua orientação" (Andrade, 2007, p. 86).

Sua lírica desse período, entretanto, é intensamente politizada e urbana. A política e a cidade imiscuem-se constantemente, seja na tradução poética da vivência no Rio de Janeiro, onde Drummond passa a residir a partir de 1934, seja pelo tratamento memorialístico de Itabira, a triste e dolorosa fotografia na parede do funcionário público: "Itabira é apenas uma fotografia na parede. Mas como dói!" (poema "Confidência do itabirano", de Sentimento do mundo, publicado em 1940).

Este artigo visa pensar, portanto, a relação do poeta com a cidade na coletânea "José", importante reunião de poemas da fase política de Drummond que é frequentemente negligenciada em favor de Sentimento do mundo ou de A rosa do povo. Visamos, assim, não somente identificar o conteúdo geográfico dos poemas, mas pensar como a cidade, a existência, a política e a poesia se imiscuem na voz de um poeta moderno que aspira pela transformação - e faz da poesia arma de resistência: "Até os poetas se armam, e um poeta desarmado é, mesmo, um ser a mercê de inspirações fáceis, dócil às modas e compromissos" (Andrade, 1944, p. 73).

Assim, fazemos uma leitura crítica dos poemas com enfoque geográfico, discutindo não só a presença da geografia na obra, mas sobretudo a relação do sujeito com o espaço. Buscamos, dessa maneira, maximizar a voz do poeta no discurso geográfico, entendendo que não cabe impor formas ou conceitos a um discurso que tem caráter libertário e trabalha com "o que há de mais delicado, de mais frágil" (Adorno, 2003, p. 65). No entanto, também entendemos que a linguagem da geografia pode contribuir e dialogar com a linguagem poética e, por isso, a expressão cartográfica é um dos elementos da nossa interpretação crítica.

\section{José, para onde?}

"José" é uma obra curiosa na produção poética de Carlos Drummond de Andrade. Reunião de 12 poemas que totalizam 20 páginas, foi publicada em 1942, mas no interior de sua primeira antologia poética, "Poesias", editada pela José Olympio. Eram "poemas novos, publicados sob o título geral de José, tirado de um dos poemas" (Gledson, 1981, p. 141). É usualmente lida, inclusive por sua extensão, como obra de transição entre Sentimento do mundo (1940) e A rosa do povo (1945) e se caracteriza, segundo o mesmo Gledson (1981, p. 141), "por uma confiança crescente, que contém tensões, mas que precisamente as contém, e que não põe à prova a relação do poeta com o mundo da maneira totalizadora característica de muitos poemas de A rosa do povo", mas em que o eu lírico se vê cada vez mais como ator. $\bigcirc$ crítico também identifica a enorme importância do espaço nos poemas e mostra que o livro contém interpretações fundamentais da vida contemporânea. 
Por conta disso, é um livro em que a presença da cidade é fundamental. A coletânea se inicia pelo Rio - "Nesta cidade do Rio", primeiro verso do primeiro poema, "A bruxa" (Andrade, 1983, p. 88) - e se encerra em Itabira - "As águas cobrem o bigode, / a familia, Itabira, tudo", últimos versos do último poema, "Viagem na familia" (Andrade, 1983, p. 108). Ao menos seis poemas da reunião se relacionam diretamente com a problemática urbana, isto é, metade da obra, e certamente entre esses estão os poemas mais importantes e significativos, como "A bruxa", "O boi", "Edifício Esplendor", "Rua do olhar" e "Os rostos imóveis".

Reflitamos primeiramente sobre o poema que dá nome à obra, "José":

E agora, José?

A festa acabou,

a luz apagou,

o povo sumiu,

a noite esfriou,

e agora, José?

e agora, você?

você que é sem nome,

que zomba dos outros,

você que faz versos,

que ama, protesta?

e agora, José?

Está sem mulher,

está sem discurso,

está sem carinho,

já não pode beber,

já não pode fumar,

cuspir já não pode,

a noite esfriou,

o dia não veio,

o bonde não veio,

o riso não veio,

não veio a utopia

e tudo acabou

e tudo fugiu

e tudo mofou,

e agora, José? (Andrade, 1983, p. 101-102).

Aqui, parece-nos que o eu lírico fala a outro, mas fala também a si mesmo. Quem é José? José é, em primeiro lugar, a simplicidade, o nome comum do homem comum, a escolha da humildade como forma de se colocar no mundo e de procurar o seu lugar no mundo. É significativo 
que esse poema tenha sido escolhido para nomear a obra como um todo: José é também o anjo torto ("Vai, Carlos, ser gauche na vida"), o deslocado, o canhestro, o desajeitado, que se afirma por meio da humildade de um poeta que não tem vergonha de se dirigir diretamente ao homem comum e faz disso valor artístico, como tantos membros do modernismo. José é, nesse sentido, uma posição política.

É também a desilusão histórica, cristalizada no seu verso de abertura, "E agora, José?", e no ambiente de desesperança onde tudo acabou, fugiu, mofou. José é o homem espoliado, inclusive espiritualmente, e reduzido ao núcleo de uma humildade infligida, exposta em seu nome: "não veio a utopia" e José, "homem partido", ficou sozinho no escuro:

Sozinho no escuro

qual bicho-do-mato,

sem teogonia,

sem parede nua

para se encostar,

sem cavalo preto

que fuja a galope,

você marcha, José!

José, para onde? (Andrade, 1983, p. 103).

homem espoliado segue sua marcha: para onde? É importante ter em mente que a poesia de Drummond cristaliza um conflito existencial que explora profundamente as antíteses e sintetiza "um vasto sistema de oposições" (Sant'Anna, 1972, p. 17). José é, assim, uma posição política, que caminha claramente no rumo do irmanar-se ao homem comum, ao excluído, mas também está carregada de ceticismo, dúvida, indecisão. José, para onde?

\section{A anticidade}

Assim, a política se apresenta entrecortada pelo ceticismo e pelo passo mais canhestro, que não aponta necessariamente um caminho político bem definido. Manifesta-se, nesse ínterim, a expressão de uma melancolia que se volta ao cotidiano da cidade e às relações sociais, desfiando o conteúdo político a partir das frustrações afetivas do sujeito, cuja solidão é marcante em diversos poemas - como o inaugural, por exemplo, "A bruxa":

Nesta cidade do Rio,

de dois milhões de habitantes,

estou sozinho no quarto,

estou sozinho na América.

Estarei mesmo sozinho?

Ainda há pouco um ruído

anunciou vida ao meu lado.

Certo não é vida humana, 
mas é vida. E sinto a bruxa presa na zona de luz.

De dois milhões de habitantes!

E nem precisava tanto...

Precisava de um amigo, desses calados, distantes, que lêem verso de Horácio mas secretamente influem na vida, no amor, na carne. Estou só, não tenho amigo, e a essa hora tardia como procurar amigo?

E nem precisava tanto. Precisava de mulher que entrasse neste minuto, recebesse este carinho, salvasse do aniquilamento um minuto e um carinho loucos que tenho para oferecer.

Em dois milhões de habitantes, quantas mulheres prováveis interrogam-se no espelho medindo o tempo perdido até que venha a manhã trazer leite, jornal e calma. Porém a essa hora vazia como descobrir mulher?

Esta cidade do Rio! Tenho tanta palavra meiga, conheço vozes de bichos, sei os beijos mais violentos, viajei, briguei, aprendi. Estou cercado de olhos, de mãos, afetos, procuras. Mas se tento comunicar-me o que há é apenas a noite e uma espantosa solidão. 
Companheiros, escutai-me!

Essa presença agitada

querendo romper a noite

não é simplesmente a bruxa.

É antes a confidência

exalando-se de um homem (Andrade, 1983, p. 88-89).

Aqui se estabelece claramente uma dialética solidão-multidão, o destaque à numerosa população da metrópole reforçando o sentimento de solidão do sujeito, "sozinho no quarto", "sozinho na América": "Quem não sabe povoar sua solidão tampouco sabe ficar só numa turba azafamada", afirma Baudelaire (2010, p. 39). Neste poema, Drummond tenta, com certo desespero, povoar sua solidão. E o fracasso dessa luta, evidenciado pelos versos "Mas se tento comunicar-me/ o que há é apenas a noite/ e uma espantosa solidão", atesta o poder de "aniquilamento" da multidão, que oprime e desagrega.

que há, aqui, de político? Justamente essa revelação da tensão indivíduo-sociedade, o primeiro revelando as carências subjetivas que se originam na fragilização da segunda, uma marca sensível da modernidade que os poetas captam com muita propriedade - entre eles, sem nenhuma dúvida, Baudelaire se destaca. Em "A bruxa", porém, essa tensão chega ao nível da desumanização, bem caracterizada na segunda estrofe ("Ainda há pouco um ruído/ anunciou vida ao meu lado./ Certo não é vida humana,/ mas é vida. E sinto a bruxa/ presa na zona de luz"), uma desumanização nitidamente articulada com a ambientação da metrópole, que impõe o isolamento e a segmentação.

Há aqui uma visão de cidade, que é uma visão política. É a cidade da aridez, da angústia, de um individualismo que nasce na dor do desamparo, a cidade que se volta contra o urbano, a cidade moderna, industrial, a "não-cidade" apontada por Lefebvre (2002, p. 25), que é materialidade mas não realiza, à plenitude, seu caráter de relação social: a anticidade.

\section{O homem de rebanho}

Essa desumanização, revelada com evidentes contornos críticos, sobretudo tendo em vista o tipo de poesia que Drummond está produzindo nesse período, é uma marca muito forte do livro de 1942, e a cidade se reafirma constantemente como seu contexto. Por exemplo, no poema "O boi":

Ó solidão do boi no campo,

Ó solidão do homem na rua!

Entre cartas, trens, telefones,

Entre gritos, o ermo profundo.

Ó solidão do boi no campo,

Ó milhões sofrendo sem praga!

Se há noite ou sol, é indiferente,

A escuridão rompe com o dia. 
Ó solidão do boi no campo,

Homens torcendo-se calados!

A cidade é inexplicável

E as casas não têm sentido algum.

Ó solidão do boi no campo!

navio-fantasma passa

Em silêncio na rua cheia.

Se uma tempestade de amor caísse!

As mãos unidas, a vida salva...

Mas o tempo é firme. $\bigcirc$ boi é só.

No campo imenso a torre de petróleo (Andrade, 1983, p. 89-90).

A desumanização, aqui, começa pela analogia. $\bigcirc$ "homem na rua", leia-se, na cidade, cercado por carros, trens, telefones, parece tão solitário e errático quanto o "boi no campo". Uma desumanização, assim, que se realiza pela animalização. No burburinho da cidade, na sua multidão de objetos, pessoas, estímulos, se dissemina um "ermo profundo", um enorme vazio. A condição subjetiva do homem que periclita nesse vazio não está tão distante da cândida brutalidade do animal a pastar. Na terceira estrofe, sobretudo, em que parece ser o homem a sentir a solidão do boi ("Ó solidão do boi no campo,/ Homens torcendo-se calados"), homem e gado se confundem sobre o pano de fundo da cidade, inexplicável e inexprimível.

Lemos, aqui, um juízo de valor sobre a cidade e sobre a modernidade. Há uma brutalização da vida humana realizada pelas forças do mundo moderno - brutalização que encontra no boi, tão frequentemente tomado como símbolo de alienação, uma contundente e engenhosa expressão lírica. Há, também, algo de nietzschiano, uma recuperação da crítica ao "instinto de rebanho", ao "homem de rebanho", aquele que se entrega ao tépido colo da coletividade e dos valores grupais, que segue acriticamente o seu pastor, como o escravo se entrega ao capataz. Esse é o "homem decadente", formado sobretudo pela moral cristã, que Nietzsche (1998, p. 125, grifos do original) lê como uma moral da mediocridade, que anula a força da vontade e a vontade de poder:

Todos os doentes, todos os doentios, buscam instintivamente organizar-se em rebanho, na ânsia de livrar-se do surdo desprazer e do sentimento de fraqueza: o sacerdote ascético intui esse instinto e o promove; onde há rebanho, é o instinto de fraqueza que o quis, e a sabedoria do sacerdote que o organizou. Pois atente-se para isso: os fortes buscam necessariamente dissociar-se, tanto quanto os fracos buscam associar-se; quando os primeiros se unem, isso acontece apenas com vista a uma agressão coletiva, uma satisfação coletiva da sua vontade de poder, com muita oposição da consciência individual; os fracos, ao contrário, se agrupam, tendo prazer nesse agrupamento.

Essa crítica moral tem repetidamente sua artilharia voltada na direção do homem moderno, sobretudo em "Além do bem e do mal": 
Supondo que se pudesse abarcar, com o olho irônico e distanciado de um deus epicúreo, a comédia singularmente dolorosa do cristianismo europeu, ao mesmo tempo grosseira e sutil, creio que não haveria limites para o espanto e o riso: pois não parece que apenas uma vontade dominou a Europa por dezoito séculos, a de fazer do homem um sublime aborto? Mas aquele que com necessidades opostas, não mais de maneira epicúrea, mas com algum divino martelo nas mãos, se aproximasse dessa degeneração e atrofia quase voluntária que é o europeu cristão (Pascal, por exemplo), deveria gritar com raiva, com pena e com horror: "Ó estúpidos, presunçosos e compassivos estúpidos, que fizeram vocês!? Isso era trabalho para suas mãos? Deformaram e estragaram minha pedra mais bela! A quanto se atreveram vocês!" - Em outras palavras: o cristianismo foi, até hoje, a mais funesta das presunções. Homens sem dureza e elevação suficientes para poder, como artistas, dar forma ao homem; homens sem longividência e força suficientes para, com uma sublime vitória sobre si, deixar valer a lei primordial das mil formas de malogro e perecimento; homens sem nobreza suficiente para perceber o hiato e a hierarquia abissalmente diversos existentes entre homem e homem esses homens, com sua "igualdade perante Deus", governaram sempre o destino da Europa, até que finalmente se obteve uma espécie diminuída, quase ridícula, um animal de rebanho, um ser de boa vontade, doentio e medíocre, o europeu de hoje [...] (Nietzsche, 2005, p. 61, grifos do original).

É necessário lembrar que essa crítica, em Nietzsche, tem claro viés conservador. Ao "homem de rebanho", o filósofo contrapõe o elogio do aristocrata, de uma sociedade que saiba fazer a clara distinção entre os fortes e os fracos, e em que os fortes se possam sobressair sem envergonhar-se de sua força, ao contrário do que ocorre na cultura cristã, que prega a humildade e a subserviência: "Toda elevação do tipo 'homem' foi, até o momento, obra de uma sociedade aristocrática - e assim será sempre: de uma sociedade que acredita numa longa escala de hierarquias e diferenças de valor entre um e outro homem" (Nietzsche, 2005, p. 153), afirma o filósofo. Esse viés encaminha uma crítica à democracia como sistema da mediocridade, que empodera o fraco e enfraquece o forte, tornando a todos medianos.

Esse é um dos fatores que dificultam o diálogo entre o pensamento nietzschiano e o marxismo. Gyorgy Lukács, por exemplo, elabora uma das mais densas interpretações do pensamento de Nietzsche, situando-o historicamente no período de decadência da intelectualidade burguesa, que se segue à revolução de 1848 e marca as últimas décadas do século XIX: "El 'encargo social' que la filosofía de Nietzsche viene a cumplir consiste en 'salvar', en 'rescatar' a este tipo de intelectual burgués, en señalarle un camino que haga innecesaria su ruptura y hasta todo conflicto serio con la burguesía [...] [o que faz dele] el filósofo más descollante de la reacción imperialista" (Lukács, 1959, p. 255/257).

Além do mais, sua evidente resistência ao socialismo e sua explícita defesa de uma Alemanha imperial, tornam-no, para Lukács, um dos precursores do nazismo - embora essa associação seja refutada por outros intérpretes. Também há um intenso debate sobre o caráter 
dialético ou não dialético do pensamento nietzschiano (Marton, 2009) - um caráter não dialético, ou mesmo antidialético, representando um evidente obstáculo ao diálogo com o marxismo.

Não obstante, a crítica nietzschiana ao "instinto de rebanho" encontra eco na crítica marxista ao "homem de massas", à massificação. O sentido político é, bem entendido, muito diferente - em Nietzsche, o elogio da força e da distinção do indivíduo frente à mediocridade do homem ordinário; no marxismo, a crítica radical à alienação produzida pelas estruturas sociais. De qualquer maneira, entretanto, encontramos a expressão de uma radical crítica social.

Que se faz presente no poema de Drummond. A cidade moderna massifica. Nessa massificação se estabelecem relações superficiais, no diapasão do consumo e da forma mercadoria, que impõem a cisão e a alienação - reforçamos que o boi, nesse sentido, deve ser lido como símbolo tanto de alienação quanto de desumanização. Aqui também está presente a dialética solidão-multidão, o ser que está só entre coisas, e só entre seres coisificados. Há, em nossa opinião, a marca dessa melancolia nos versos de Drummond, e ela se associa muito claramente à posição política assumida pelo poeta - mesmo esparsa e algo cética - nesse momento de sua produção literária: a posição crítica frente à modernidade e à cidade moderna.

\section{Células estanques}

Nada disso é acaso, exceção, acidente de percurso. Os poemas consolidam-se uns aos outros. Quando entendemos a necessidade de ir além da leitura fragmentária que a poesia moderna permite e até induz, quando procuramos ler e interpretar as obras na sua totalidade, com a determinação de tirar os poemas do isolamento, encontramos sempre a força de um núcleo, de uma raiz, de uma tonalidade afetiva a unificá-los, mesmo que dolorosa ou erraticamente.

Essa espécie de ordem na desordem nasce da expressão mais crua, despida de floreios linguísticos ou paradigmas estéticos enrijecidos, que reflete a crueza do mundo e seus conflitos: a poesia moderna. Os poemas reverberam-se, espelham-se, (re)afirmam-se, ou, ao contrário, negam-se violentamente, numa dialética que trafega os extremos e se expressa pelo contraste, sem desencontrar-se da dúvida, da suspeita, da indecisão. $\bigcirc$ sujeito poético não é um átomo apartado da sociedade; o poema não é uma peça de coleção, que se amontoa sem propósito. $O$ dever do crítico é procurar o que os enreda - e como os enreda.

A angústia frente à alienação - entendida no sentido ideológico, mas também no sentido social de separação, apartheid, incomunicabilidade -, ao isolamento, à solidão e à mercantilização dos afetos invade outros poemas e enreda as páginas de "José" - e as obras de Drummond. Quase sempre com a cidade moderna imiscuindo-se entre os versos como forma concreta que anima personagens e objetos de crítica. A consciência dessa forma nasce claramente de uma vivência objetiva-subjetiva que se reproduz criticamente. Mas é importante apontar a recorrência dessa realização poética, que faz da geografia mais que um pano de fundo material, que destaca o valor da existência histórico-geográfica como ponto de partida da realização literária e do diálogo entre geografia e literatura.

Encontrando uma precária unidade na expressão poética do mundo estilhaçado, o poeta insiste na sua frustração frente à fragilidade dos laços e à fugacidade dos eventos da existência material, que a escritura poética per se não transforma. Essa frustração, novamente, revela 
o desejo por "algo mais" - algo mais profundo, algo mais denso, algo mais perene, mais duradouro, mais pleno - e recupera, de forma algo sub-reptícia, o grito de "Brejo das Almas": "sim! Ao eterno". A poesia é uma maneira de transformar a existência material, mas também ela, em diversos momentos e ocasiões, revela sua fragilidade. $O$ longo e seminal poema "Edifício Esplendor" adquire, assim, centralidade:

Na areia da praia

Oscar risca o projeto.

Salta o edifício

da areia da praia.

No cimento, nem traço

da pena dos homens.

As famílias se fecham

em células estanques.

O elevador sem ternura

expele, absorve

num ranger monótono

substância humana.

Entretanto há muito

se acabaram os homens

Ficaram apenas

tristes moradores.

II

A vida secreta da chave.

Os corpos se unem e

bruscamente se separam.

O copo de uísque e o blue

destilam ópios de emergência.

Há um retrato na parede,

um espinho no coração,

uma fruta sobre o piano

e um vento marítimo com cheiro de peixe, tristeza, viagens...

Era bom amar, desamar,

morder, uivar, desesperar, 
era bom mentir e sofrer.

Que importa a chuva no mar?

a chuva no mundo? o fogo?

Os pés andando, que importa?

Os móveis riam, vinha a noite,

o mundo murchava e brotava

a cada espiral de abraço.

E vinha mesmo, sub-reptício,

em momentos de carne lassa,

certo remorso de Goiás.

Goiás, a extinta pureza...

retrato cofiava o bigode.

III

Oh que saudades não tenho de minha casa paterna.

Era lenta, calma, branca, tinha vastos corredores e nas suas trinta portas trinta crioulas sorrindo, talvez nuas, não me lembro.

E tinha também fantasmas, mortos sem extrema-unção, anjos da guarda, bodoques e grandes tachos de doce e grandes cismas de amor, como depois descobrimos.

Chora, retrato, chora.

Vai crescer a tua barba neste medonho edifício de onde surge tua infância como um copo de veneno.

IV

As complicadas instalações do gás, úteis para suicídio, o terraço onde as camisas tremem, 
também convite à morte,

o pavor do caixão

em pé no elevador,

o estupendo banheiro

de mil cores árabes,

onde o corpo esmorece

na lascívia frouxa

da dissolução prévia.

Ah, o corpo, meu corpo,

que será do corpo?

Meu único corpo,

aquele que eu fiz

de leite, de ar,

de água, de carne,

que eu vesti de negro,

de branco, de bege,

cobri com chapéu,

calcei com borracha,

cerquei de defesas,

embalei, tratei?

Meu coitado corpo

tão desamparado

entre nuvens, ventos,

neste aéreo living!

V

Os tapetes envelheciam

pisados por outros pés.

Do cassino subiam músicas

e até o rumor de fichas.

Nas cortinas, de madrugada, a brisa pousava. Doce.

A vida jogada fora

voltava pelas janelas.

Meu pai, meu avô, Alberto...

Todos os mortos presentes. 
Já não acendem a luz

com suas mãos entrevadas.

Fumar ou beber: proibido

Os mortos olham e calam-se.

retrato descoloria-se, era superfície neutra.

As dívidas amontoavam-se.

A chuva caiu vinte anos.

Surgiram costumes loucos

e mesmo outros sentimentos.

- Que século, meu Deus! diziam os ratos.

E começavam a roer o edifício (Andrade, 1983, p. 91-94).

Os contornos de uma forte crítica à modernidade são, também aqui, estabelecidos desde o início. $\bigcirc$ personagem Oscar, a projetar seu edifício na areia, parece uma clara referência a Oscar Niemeyer, figura de proa da arquitetura moderna e já um fecundo e importante arquiteto no Brasil das décadas de 1930-40 - sobretudo na então capital federal, o Rio de Janeiro.

Lembremos que Drummond é nomeado chefe de gabinete de Gustavo Capanema, então ministro da Educação e Saúde, em 1934, cargo que ocupa até 1945 (Andrade, 2002, p. 123), fase que abrange seu período politicamente mais fecundo. $\bigcirc$ edifício do ministério, atual Edifício Gustavo Capanema, situado à rua da Imprensa, 16, no centro do Rio, é um dos prédios públicos cariocas projetados pela equipe de Lúcio Costa e Oscar Niemeyer. O poeta parte do espaço vivido para criar sua poesia crítica. No Mapa 1, a localização do edifício em relação à casa de Drummond. 


\section{Mapa 1 - Lugares onde Carlos Drummond de Andrade morou e trabalhou no Rio de Janeiro}

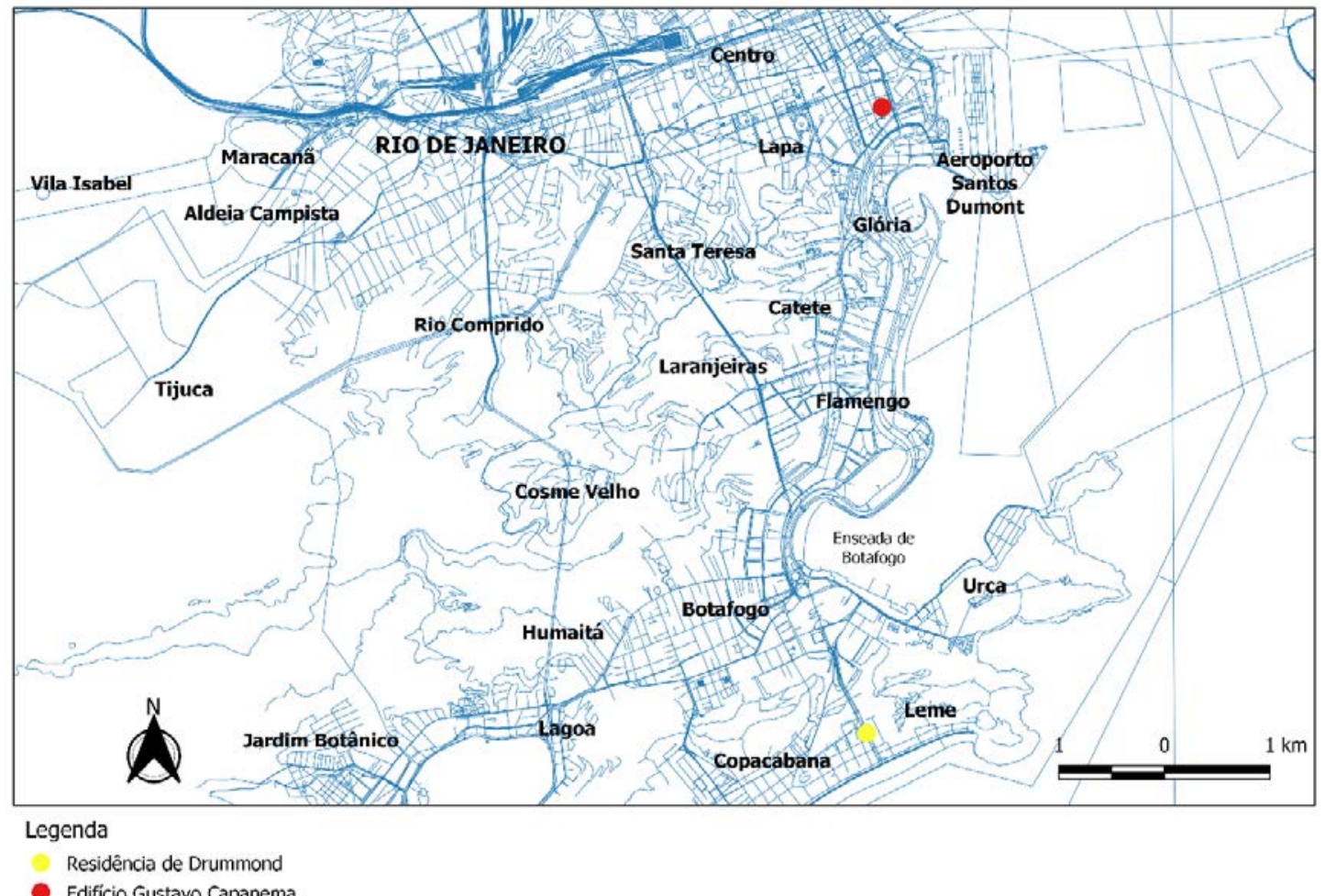

elaboração: $\bigcirc$ autor, 2019.

fonte de dados: Open Street Map, 2019.

sistema de coordenadas geográficas: datum WGS84.

Novamente, estamos diante da (anti)cidade da aridez, da angústia, do individualismo, da solidão. A força poética do traço do arquiteto é consumida no cimento cinza que encerra famílias fechadas em "células estanques", onde o ranger diuturno da modernidade consome a humanidade e a devolve numa função social esvaziada de sentido: "há muito/ se acabaram os homens/ Ficaram apenas/ tristes moradores".

O poeta vai dissecando sua solidão na metrópole, em que "os corpos se unem e/ bruscamente se separam". A embriaguez, a música, "ópios de emergência", não bastam. $\bigcirc$ melancólico itabirano que leva um "retrato na parede e um espinho no coração" é embalsamado por "um vento marítimo com cheiro de peixe, tristeza, viagens": vento da orla do Rio.

Mas a paisagem parece desfazer-se no horizonte das memórias dolorosas. "Ai que saudade não tenho": a nostalgia se afirma pela negação, dialeticamente. Uma saudade de Itabira, do casarão senhorial, das "crioulas sorrindo" na infância abastada. A nostalgia da infância, que nasce na solidão das precárias unidades do adulto, se mescla à nostalgia social de uma aristocracia que se proletarizou, e para quem o passado senhorial é ainda uma imagem grandiosa (embora não menos vazia): "Chora, retrato, chora./ Vai crescer a tua barba/ neste medonho edifício/ de onde surge tua infância/ como um copo de veneno". Nesse contexto, aparece o tema do suicídio, no capítulo IV, que aponta uma subjetividade habitando os extremos, os limites - da angústia, da solidão, da desesperança -, cercado por "convites à morte" no edifício cujo nome se reveste de ironia cáustica: Esplendor. Este parece ser o edifício da modernidade, dissolvendo a alma e 
o corpo, não menos predestinado a ser roído pelos ratos do que o passado grandioso da família senhorial: "Que século, meu Deus!".

Há nesse poema uma forte negatividade, que se evidencia sobretudo na forma como o espaço vivido é traduzido. Não há contradição no fato de que o homem é, ao mesmo tempo, "animal de rebanho" e "célula estanque": a massificação se faz justamente numa sociedade mercantil em que a humanidade se dissolve em papéis funcionais: "há muito/ se acabaram os homens/ Ficaram apenas/ tristes moradores". O moderno prédio de moradias é símbolo maior de um processo simultâneo de massificação e alienação: tão coletivo quanto absolutamente individual, institui um espaço de cisão, onde as relações sociais são preestabelecidas e a comunhão é precária. $\bigcirc$ sujeito se encerra numa célula estanque, igual a tantas outras células estanques, até tornar-se, ele próprio, célula estanque. Expondo essas vísceras sociais, e querendo ir além, a poesia se faz política.

\section{A cidade e a morte}

A imagem da cidade como organismo vivo é recorrente. Há toda uma tradição do pensamento urbanístico que caminha nesse sentido, mas também é forte a presença de metáforas orgânicas no cotidiano. Na imprensa, em notícias e debates sobre trânsito urbano, é comum o uso do termo "artéria" para referir-se às principais vias de tráfego. Em outras ocasiões, o centro se torna o "coração" da cidade, que pulsa sem parar. Por outro lado, também é comum a analogia entre a cidade e uma grande máquina cujo sistema tem funcionamento diuturno, que pode arrefecer, mas jamais cessar.

Essas imagens e metáforas revelam uma "pulsão de vida" que a cidade, obra de homens vivos, para a vida, cristaliza. A cidade é um corpo em incessante movimento e, como tal, parece projetada para nos manter longe da paralisia e da morte. Mergulhado no cotidiano urbano, em movimento contínuo, o homem pode se distrair e esquecer seu trágico destino.

No entanto, esse movimento incessante também carrega uma violência intrínseca, sobretudo na cidade moderna, onde a máquina é imperativa e o homem se dissocia definitivamente da natureza. A cidade, cada vez mais projetada para o carro, para o prédio e para o trem, cada vez mais projetada para a execução de funções mecânicas atomísticas e menos para a realização da existência e da comunhão, se volta contra as pessoas, agressivamente. Vivendo na anticidade, a humanidade se dissolve na engrenagem e se aproxima da morte. A aridez, a angústia e a solidão revelam, assim, uma forte "pulsão de morte". Em "José", Drummond irá dissolver a cidade na morte num dos poemas mais belos e melancólicos do livro, "Os rostos imóveis", que dedica a Otto Maria Carpeaux:

Pai morto, namorada morta.

Tia morta, irmão nascido morto.

Primos mortos, amigo morto.

Avô morto, mãe morta

(mãos brancas, retrato sempre inclinado na parede, grão de poeira nos olhos).

Conhecidos mortos, professora morta.

Inimigo morto. 
Noiva morta, amigas mortas.

Chefe de trem morto, passageiro morto.

Irreconhecível corpo morto: será homem? bicho?

Cão morto, passarinho morto.

Roseira morta, laranjeiras mortas.

Ar morto, enseada morta.

Esperança, paciência, olhos, sono, mover de mão: mortos.

Homem morto. Luzes acesas.

Trabalha à noite, como se fora vivo.

Bom dia! Está mais forte (como se fora vivo).

Morto sem notícia, morto secreto.

Sabe imitar fome, e como finge amor.

E como insiste em andar, e como anda bem.

Podia cortar casas, entra pela porta.

Sua mão pálida diz adeus à Rússia.

$\bigcirc$ tempo nele entra e sai sem conta.

Os mortos passam rápidos, já não há pegá-los.

Mal um se despede, outro te cutuca.

Acordei e vi a cidade:

eram mortos mecânicos,

eram casas de mortos,

ondas desfalecidas,

peito exausto cheirando a lírios,

pés amarrados.

Dormi e fui à cidade:

toda se queimava,

estalar de bambus,

boca seca, logo crispada.

Sonhei e volto à cidade.

Mas já não era a cidade.

Estavam todos mortos, o corregedor-geral verificava etiquetas nos cadáveres.

O próprio corregedor morrera há anos, mas sua mão continuava implacável.

O mau cheiro zumbia em tudo.

Desta varanda sem parapeito contemplo os dois crepúsculos.

Contemplo minha vida fugindo a passo de lobo, quero detê-la, serei mordido?

Olho meus pés, como cresceram, moscas entre eles circulam. 
Olho tudo e faço a conta, nada sobrou, estou pobre, pobre, pobre, mas não posso entrar na roda,

não posso ficar sozinho,

a todos beijarei na testa,

flores úmidas esparzirei,

depois... não há depois nem antes.

Frio há por todos os lados,

e um frio central, mais branco ainda.

Mais frio ainda...

Uma brancura que paga bem nossas antigas cóleras e amargos...

Sentir-me tão claro entre vós, beijar-vos e nenhuma poeira em boca ou rosto.

Paz de finas árvores,

de montes fragílimos lá embaixo, de ribeiras tímidas, de gestos que já não

podem mais irritar,

doce paz sem olhos, no escuro, no ar.

Doce paz em mim,

em minha familia que veio de brumas sem corte de sol

e por estradas subterrâneas regressa às suas ilhas,

na minha rua, no meu tempo - afinal - conciliado,

na minha cidade natal, no meu quarto alugado,

na minha vida, na vida de todos, na suave e profunda morte de mim e de todos

(Andrade, 1983, p. 99-101).

Em certos aspectos, esse poema parece um desdobramento de "José", onde se formaliza uma profunda desesperança histórica como parte da constituição do indivíduo: "Esperança, paciência, olhos, sono, mover de mão: mortos./ Homem morto. Luzes acesas./ Trabalha à noite, como se fora vivo". No entanto, aqui, a cidade aparece mais claramente como ambiência do desespero e da morte. Ela é também lócus da desumanização, marcada na atmosfera fúnebre e evidenciada no terceiro verso da segunda estrofe: "Irreconhecível corpo morto: será homem? bicho?".

Este é, sem dúvida, um dos poemas de mais difícil interpretação do livro de 1942. Fortemente metafórico e algo metafísico, parece escrito para arrastar o leitor a uma comunhão no desespero, na dissolução absoluta de tudo e todos, angústia profunda agravada pela onipresença exaustiva, impositiva, da morte, que alerta o leitor para a inevitabilidade de um destino comum: os dois crepúsculos, assim, a que se refere o eu lírico no primeiro verso da penúltima estrofe, parecem ser o seu e o do mundo. Do "sistema de oposições" que identifica Sant' Anna (1972, p. 17) como pedra angular da obra de Carlos Drummond de Andrade, a oposição "eu versus mundo" é a síntese. Aqui, porém, o eu e o mundo conciliam-se no destino trágico e inexorável da morte.

Também nos parece uma tentativa bastante evidente de compreensão desesperada da vida por meio da morte: "Desta varanda sem parapeito contemplo os dois crepúsculos./ Contemplo minha vida fugindo a passo de lobo, quero detê-la, serei mordido?". Assim, a morte se afasta de seu sentido literal para tornar-se uma alegoria, um símbolo do vazio absoluto de uma era: "Acordei e vi a cidade:/ eram mortos mecânicos, / eram casas de mortos, / ondas desfalecidas, / peito exausto cheirando 
a lírios,/ pés amarrados". A sequência do encontro com a cidade, "Acordei e vi a cidade", "Dormi e fui à cidade", "Sonhei e volto à cidade", com a persistência da morte nas três situações, indica com muita propriedade essa mixórdia entre sonho e vigilia, sentidos literais e sentidos figurados.

Em "As cidades invisíveis", de Ítalo Calvino, há duas cidades muito relevantes para pensarmos o tema da morte. Em Adelma, cada rosto avistado pelo visitante lhe recorda alguém que já morreu: "Se Adelma é uma cidade que vejo no mundo dos sonhos", aponta o viajante, "onde não há nada além de mortos, sinto medo do sonho. Se Adelma é uma cidade real, habitada por vivos, se eu continuar a fita-los as semelhanças se dissolverão e eles parecerão estranhos portadores de angústia” (Calvino, 1990, p. 89).

Laudômia, por outro lado, é uma "cidade tripla", composta pela cidade dos vivos, pela cidade dos mortos e pela dos "não-nascidos". Na cidade dos vivos como na dos mortos, o traçado das ruas e a sequência das casas são idênticos, e os mortos têm os mesmos nomes dos vivos: "Nas tardes ensolaradas, a população vivente visita os mortos e decifra os próprios nomes nas lajes de pedra", e ambas as cidades comunicam "uma história de sofrimentos, irritações, ilusões, sentimentos"; mas na cidade dos mortos, "tudo se tornou necessário, livre do acaso, arquivado, posto em ordem. E, para se sentir segura, a Laudômia viva precisa procurar na Laudômia dos mortos a explicação de si própria" (Calvino, 1990, p. 127).

Há algo de Adelma e de Laudômia na cidade deste poema. A cada rosto, um morto ("rostos imóveis") - ou um "estranho portador de angústia"? E a cidade dos "mortos mecânicos", onde o eu lírico parece trafegar - parte em sonho, parte em vigília -, é onde busca alguma explicação de si próprio. E há, como em Laudômia, uma ordem, uma paz encontrada na morte, como evidencia a última estrofe.

Essa presença tão forte e insistente da morte deve ser considerada contraditória com a política? Se considerarmos, rigorosamente, que só há política na "pulsão de vida", que a política envolve, de um lado, uma aspiração de futuro que só tem lugar no "mundo dos vivos" e, de outro, a "vontade de poder" que nasce dos instintos como inevitabilidade carnal e terrena, então a morte é uma contradição. E é contradição também com a cidade, se considerada exclusivamente em sua positividade, para além de sua face violenta. Mas não se pode esquecer que enfrentar a morte - mesmo que por meio de uma aceitação resignada - é um ato de resistência, sobretudo numa civilização que institui todo um sistema de crenças e valores orientados para a fuga simbólica dessa inevitabilidade.

Esse poema parece cristalizar toda a carga de angústia com a qual Drummond está lidando nesse período, que tem relação, sem dúvida, com o momento histórico do início da década de 1940, carregado de aflição e desespero. Também é bastante evidente a consciência do poeta do papel que desempenham as forças da modernidade, materializadas na cidade, na sedimentação dessa angústia. A persistência da morte é, frente a elas, símbolo do vazio e da paralisia que marcam uma era.

\section{Considerações finais}

A aproximação entre geografia e literatura oferece múltiplas perspectivas de enriquecimento mútuo. Como ciência de "longa tradição conservadora" (Corrêa, 1980, p. 8), entretanto, 
por muito tempo a geografia não viu na literatura mais que um repositório de imagens, percepções e informações geográficas a serem incorporadas na pesquisa sem grandes problematizações. Por isso, formas literárias mais próximas ao pensamento científico, como o romance realista, gozaram de certa predileção até que os geógrafos começassem a problematizar o próprio discurso, os limites da representação e as relações entre o real e a ficção.

A poesia moderna representa, nesse sentido, um universo antitético que, pelo tensionamento do discurso (literário e científico) e pela desconstrução da forma, oferece novas possibilidades de reflexão ao pensamento geográfico. Além do mais, sofrendo o impacto e a influência da modernidade nos planos discursivo, temático e estético, a arte acaba por conectar-se intensamente à temática urbana. Assim, a poesia drummondiana, já intensamente política, torna-se também existencial. E o principal espaço de existência da modernidade é a cidade.

Dessa maneira, oferecemos aqui uma leitura do universo existencial de uma das obras mais importantes e negligenciadas da fase mais politizada daquele que Antonio Candido veio a definir como "o maior poeta social da nossa literatura contemporânea": "José", uma obra em que a simplicidade do nome comum do homem comum embasa elevadas expressões e reflexões sobre a vida, a modernidade e a cidade.

Muitas vezes, além de seu apetite por repertoriar imagens, percepções e informações geográficas, a geografia também olha para a arte ansiosa por encontrar o espaço sendo feito, produzido. A arte claramente criando formas espaciais concretas, palpáveis. Há uma dificuldade de perceber que há geografia até mesmo no homem solitário refletindo sobre sua vida, seu espaço, sua cidade, seu cotidiano.

Afinal, que é a geografia senão isso, senão o homem refletindo sobre todos os aspectos de sua dimensão espacial? Como nos diz Dardel (2015, p. 1), "[...] a inquietude geográfica precede e sustenta a ciência objetiva". O pensamento geográfico não se restringe aos geógrafos ou aos muros de universidades e institutos de pesquisa. Está nas ruas, está nas esquinas e calçadas, está nos poemas, nas músicas, nos filmes, nas pinturas, nos grafites que se espalham pelos muros da cidade.

"A 'geografia' permanece, habitualmente, discreta, mais vivida que exprimida" (Dardel, 2015, p. 34). A arte, assim, antes de ser a geografia exprimida, é a geografia vivida. E isso fica claro nos poemas de Drummond: como são importantes, na constituição desse poeta como ser, o espaço vivido, o cotidiano e as relações sociais nesse espaço. As dimensões política e geográfica dialogam constantemente, fazendo do espaço um espaço de existência e resistência. A politização de sua lírica se volta contra as estruturas da modernidade, em que o poeta já não "consegue integrar-se, feliz, nos discursos correntes da sociedade" (Bosi, 2000, p. 165).

Em "José", fica evidente um enfrentamento negativo que terá sua explosão definitiva em 1945, com a publicação de A rosa do povo, "uma das grandes obras da literatura participante no Brasil” (Simon, 1978, p. 59). Procuramos demonstrar aqui a dimensão geográfica desse enfrentamento e a fecundidade da obra de Drummond para a interpretação geográfica da modernidade e da cidade moderna.

\section{Referências}

ADORNO, T. W. Notas de literatura I. São Paulo: Duas Cidades/Ed. 34, 2003. 
ANDRADE, C. D. Sentimento do mundo. 23. ed. Rio de Janeiro: Record, 2007.

ANDRADE, C. D. Alguma poesia. Rio de Janeiro: Record, 2002.

ANDRADE, C. D. Nova reunião: 19 livros de poesia. Rio de Janeiro: José Olympio, 1983.

ANDRADE, C. D. Confissões de Minas. Rio de Janeiro: Americ-Edit, 1944.

BAUDELAIRE, C. $\mathbf{O}$ esplim de Paris: pequenos poemas em prosa. São Paulo: Martin Claret, 2010.

BOSI, A. O ser e o tempo da poesia. São Paulo: Companhia das Letras, 2000.

BROSSEAU, M. Des romans géographes. Paris: L'Harmattan, 1996.

CALVINO, I. As cidades invisíveis. São Paulo: Companhia das Letras, 1990.

CANDIDO, A. Inquietudes na poesia de Drummond. In: CANDIDO, A. Vários escritos. 5. ed. Rio de Janeiro: Ouro Sobre Azul, 2011. p. 69-99.

CANDIDO, A. Formação da literatura brasileira. 3. ed. São Paulo: Martins, 1969.

CORREAA, R. L. Da nova geografia à geografia nova. Revista de Cultura Vozes, Petrópolis, RJ, v. 74, p. 5-12, 1980.

DARDEL, E. O homem e a terra: natureza da realidade geográfica. São Paulo: Perspectiva, 2015.

GLEDSON, J. Poesia e poética de Carlos Drummond de Andrade. São Paulo: Duas Cidades, 1981.

LAFAILLE, R. Départ: Géographie et poésie. The Canadian Geographer, v. 33, n. 2, p. 118-130, 1989. doi: https://doi.org/10.1111/j.1541-0064.1989.tb00893.x.

LEFEBVRE, H. A revolução urbana. Belo Horizonte: Ed. UFMG, 2002.

LUKÁCS, G. El asalto a la razón: la trayectoria del irracionalismo desde Schelling hasta Hitler. México: Fondo de Cultura Económica, 1959.

MARTON, S. Nietzsche e Hegel, leitores de Heráclito. In: MARTON, S. Extravagâncias: ensaios sobre a filosofia de Nietzsche. São Paulo: Discurso/Barcarolla, 2009. p. 119-142.

NIETZSCHE, F. Além do bem e do mal: prelúdio a uma filosofia do futuro. São Paulo: Companhia das Letras, 2005.

NIETZSCHE, F. Genealogia da moral. São Paulo: Companhia das Letras, 1998.

SANT'ANNA, A. R. Drummond: o gauche no tempo. Rio de Janeiro: Lia/Editor, 1972.

SIMON, I. M. Drummond: uma poética do risco. São Paulo: Ática, 1978.

Recebido em: 3 maio 2021 Aprovado em: 13 maio 2021 